\title{
High Prevalence of Clonorchis sinensis and Other Zoonotic Trematode Metacercariae in Fish from a Local Market in Yen Bai Province, Northern Vietnam
}

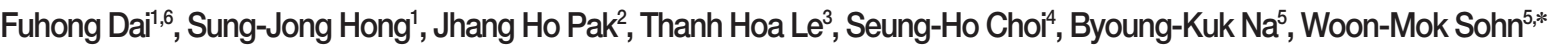 \\ 'Department of Environmental Medical Biology, Chung-Ang University College of Medicine, Seoul 06974, Korea; ${ }^{2}$ Asan Institute for Life Sciences, University \\ of Ulsan College of Medicine, Asan Medical Center, Seoul 05505, Korea; ${ }^{3}$ Department of Immunology, Institute of Biotechnology, Vietnam Academy of \\ Science and Technology, Hanoi, Vietnam; ${ }^{4}$ Society of Korean Naturalist, Institute of Ecology and Conservation, Yangpyeong 12563, Korea; ${ }^{5}$ Department of \\ Parasitology and Tropical Medicine, and Institute of Health Sciences, Gyeongsang National University College of Medicine, Jinju 52727, Korea, ${ }^{6}$ Department \\ of Parasitology, School of Biology and Basic Medical Sciences, Medical College, Soochow University, Suzhou, Jiangsu 215123, P.R. China
}

\begin{abstract}
A small survey was performed to investigate the recent infection status of Clonorchis sinensis and other zoonotic trematode metacercariae in freshwater fish from a local market of Yen Bai city, Yen Bai province, northern Vietnam. A total of 118 fish in 7 species were examined by the artificial digestion method on March 2016. The metacercariae of 4 species of zoonotic trematodes, i.e., C. sinensis, Haplorchis pumilio, Haplorchis taichui, and Centrocestus formosanus, were detected. The metacercariae of $C$. sinensis were found in 62 (69.7\%) out of 89 fish (5 species), and their intensity of infection was very high, 81.2 per fish infected. Prevalences of 3 intestinal flukes, $H$. pumilio, $H$. taichui and $C$. formosanus, were $75.0 \%, 47.6 \%$, and $31.7 \%$ in positive fish species, respectively, with the metacercarial intensities of $15.5,10.3$, and 2.2 per fish infected. From the above results, it has been confirmed that various species of freshwater fish continue to play the role of the infection source of $C$. sinensis and other zoonotic trematodes in Yen Bai city, Yen Bai province, northern Vietnam. It is of particular note that the prevalence and intensity of $C$. sinensis metacercariae are much higher than those reported in previous studies in fish in northern Vietnam.
\end{abstract}

Key words: Clonorchis sinensis, Haplorchis pumilio, Haplorchis taichui, Centrocestus formosanus, zoonotic trematode metacercaria (ZTM), Yen Bai province, Vietnam

Fishborne zoonotic trematode (FZT) infections, including Clonorchis sinensis, affect the health of more than 30 million people throughout the world and are particularly prevalent in Asian countries, such as Lao PDR, Vietnam, Cambodia, Thailand, Philippines, Taiwan, China, and Korea [1-4]. Human infections with FZT are almost entirely caused by the habitual consumption of raw and/or undercooked fish meat containing infective larvae, the metacercariae [4-6]. Surveys on the infection status of fish with zoonotic trematode metacercariae (ZTM) have been conducted by many workers to obtain useful information on the epidemiology of zoonotic trematodes in particular areas [7-11]. In Vietnam, epidemiological surveys for ZTM were performed on fish intermediate hosts in local areas by many workers [8,12-22]. Especially, Chai et al. [8] surveyed

- Received 24 March 2020, revised 19 May 2020, accepted 20 May 2020.

*Corresponding author (wmsohn@gnu.ac.kr)

(c) 2020, Korean Society for Parasitology and Tropical Medicine

This is an Open Access article distributed under the terms of the Creative Commons

Attribution Non-Commercial License (https://creativecommons.org/licenses/by-nc/4.0) which permits unrestricted non-commercial use, distribution, and reproduction in any

medium, provided the original work is properly cited. the infection status of ZTM in wild fish from 2 localities of northern Vietnam, Hanoi city and Nam Dinh province, and they also described the morphological characteristics of ZTM and their adults recovered from experimental animals. However, most of the studies were performed on fish from adjacent and/or lower latitude areas of Hanoi [8,12-22].

Yen Bai province is an agricultural-based province located in the northern part of north-central Vietnam. The Red River (midle reach) and the Thac Ba Lake are ecologically important for the source of fish in inhabitants of this province [23]. Furthermore, there are no available information to know the infection status of ZTM in fish intermediate hosts, which is a kind of valuble protein source for the people in this region. Therefore, we performed a small survey to know the infection status of ZTM among wild fish purchased from a local market of Yen Bai city, Yen Bai province, northern Vietnam.

A total of 118 freshwater fish in 7 species were collected from a local market of Yen Bai city (latitude: 21.699533; longitude:104.879628), Yen Bai province, northern Vietnam on March 2016 (Fig. 1) [23]. All collected fish were transferred 


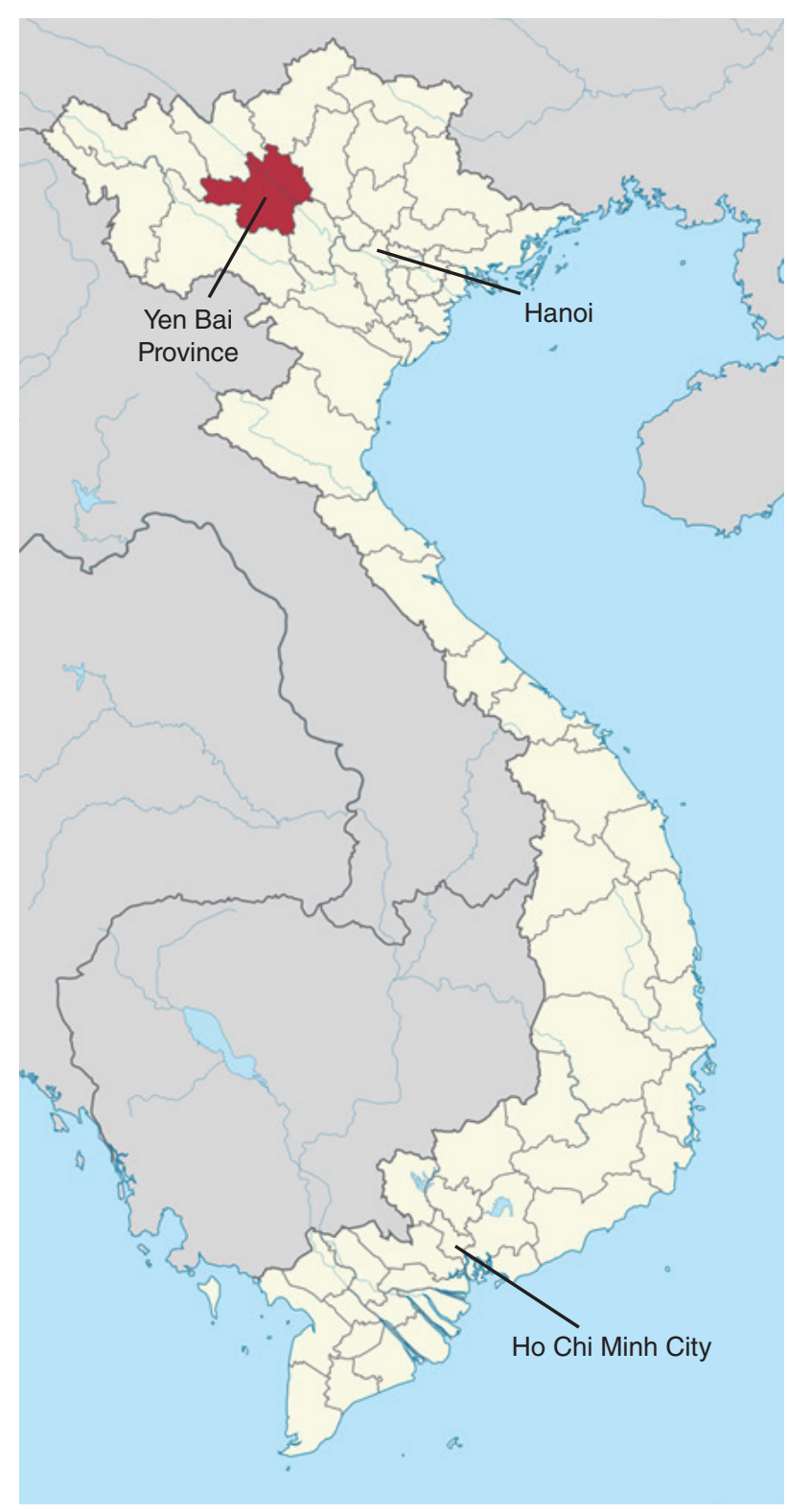

Fig. 1. The surveyed area (red region), Yen Bai province, northern Vietnam (from Wikipedia website [23]). with ice to the laboratory of Department of Parasitology and Tropical Medicine, Gyeongsang National University College of Medicine, Jinju, Korea. Their length and weight were individually measured and the fish species were identified with the aid of a Korean ichthyologist and Search FishBase site in internet (Table 1) [24]. Individual fish was finely ground in a mortar with pestle, the ground fish meat was mixed with artificial gastric juice, and the mixture was incubated at $36^{\circ} \mathrm{C}$ for about 2 hr. The digested material was filtered through a $1 \times 1 \mathrm{~mm}^{2}$ of mesh, and washed with $0.85 \%$ saline until the supernatant became clear. The sediment was carefully examined under a stereomicroscope. The metacercariae of each species (only ZTM) were separately collected viewing from the general feature and counted to get hold of the prevalence (\%) and intensity of infection (no. of ZTM per fish infected) by fish species [5].

Total 4 species of trematode metacercariae, i.e., C. sinensis, Haplorchis pumilio, Haplorchis taichui, and Centrocestus formosanus, were detected. The prevalence of $C$. sinensis metacercariae were very high to be positive in $62(69.7 \%)$ out of 89 fish in 5 species, i.e., Chanodichthys erythropterus (Fig. 2A), Toxabramis houdemeri (Fig. 2B), Saurogobio immaculatus, Opsariichthys bidens, and Squalidus atromaculatus, with the average intensity of 81.2 per fish infected. The metacercariae of 3 intestinal flukes, i.e., H. pumilio, H. taichui, and C. formosanus, were detected in $75.0 \%, 47.6 \%$, and $31.7 \%$ of positive fish groups, respectively, and their mean intensities were 15.5, 10.3, and 2.2 per fish infected. The infection status of each ZTM by fish species is designated in (Table 2).

The metacercariae $(\mathrm{n}=20)$ of $C$. sinensis were elliptical and 140-175 (159 in average) by 120-160 (142) $\mu \mathrm{m}$ in size. They had nearly equal sized oral and ventral suckers, brownish pigment granules in the body, and an O-shaped excretory bladder in the posterior portion. The adult worms (40-day-old from

Table 1. Fish collected from a local market in Yen Bai city, Yen Bai province, Vietnam

\begin{tabular}{|c|c|c|c|c|c|}
\hline \multirow{2}{*}{ Species of fish } & \multirow{2}{*}{$\begin{array}{l}\text { No. of fish } \\
\text { examined }\end{array}$} & \multicolumn{2}{|c|}{ Length } & \multicolumn{2}{|c|}{ Weight } \\
\hline & & Range & Average & Range & Average \\
\hline Chanodichthys erythropterus & 30 & $9.6-13.2$ & 11.2 & $10.9-31.3$ & 19.3 \\
\hline Toxabramis houdemeri & 30 & $7.5-9.4$ & 8.1 & $5.4-10.2$ & 6.6 \\
\hline Carassius auratus & 27 & $8.1-12.9$ & 9.9 & $12.3-50.6$ & 23.9 \\
\hline Saurogobio immaculatus & 10 & $6.4-11.2$ & 9.3 & 3.9-17.2 & 10.8 \\
\hline Opsariichthys bidens & 10 & - & - & $14.0-28.0$ & 21.8 \\
\hline Squalidus atromaculatus & 9 & 7.3-8.0 & 7.7 & $6.2-9.0$ & 7.6 \\
\hline Garra imbarbatus & 2 & - & 7.0 & $7.4-7.5$ & 7.5 \\
\hline
\end{tabular}

\footnotetext{
${ }^{a}$ Total 118 fish in 7 species were examined.
} 

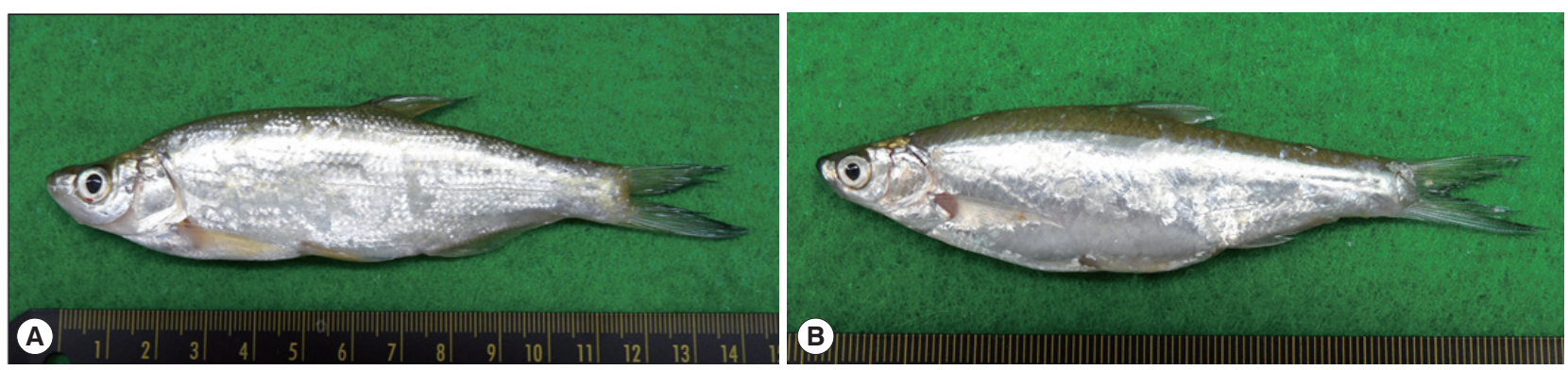

Fig. 2. Susceptible fish hosts, Chanodichthys erythropterus (A), Toxabramis houdemeri (B), to C. sinensis metacercariae in the surveyed area, Yen Bai city, Yen Bai province, northern Vietnam.

Table 2. Infection status of zoonotic trematode metacercariae (ZTM) by the fish species from a local market in Yen Bai city, Yen Bai province, Vietnam

\begin{tabular}{|c|c|c|c|c|}
\hline \multirow{2}{*}{ ZTM and fish species infected } & \multirow{2}{*}{ No. of fish examined } & \multirow{2}{*}{ Infection rate (\%) } & \multicolumn{2}{|c|}{ No. of ZTM detected } \\
\hline & & & Range & Average \\
\hline \multicolumn{5}{|l|}{ Clonorchis sinensis } \\
\hline Chanodichthys erythropterus & 30 & 93.3 & $2-521$ & 105.5 \\
\hline Toxabramis houdemeri & 30 & 100 & $8-179$ & 69.1 \\
\hline Saurogobio immaculatus & 10 & 2.0 & - & 1.0 \\
\hline Opsariichthys bidens & 10 & 10.0 & - & 1.0 \\
\hline Squalidus atromaculatus & 9 & 11.1 & - & 1.0 \\
\hline Subtotal & 89 & 69.7 & $1-521$ & 81.2 \\
\hline \multicolumn{5}{|l|}{ Haplorchis pumilio } \\
\hline Chanodichthys erythropterus & 30 & 100 & $2-152$ & 28.6 \\
\hline Carassius auratus & 27 & 70.4 & $1-14$ & 4.9 \\
\hline Toxabramis houdemeri & 20 & 75.0 & $1-19$ & 4.5 \\
\hline Squalidus atromaculatus & 9 & 11.1 & - & 1.0 \\
\hline Garra imbarbatus & 2 & 50.0 & - & 3.0 \\
\hline Subtotal & 88 & 75.0 & $1-152$ & 15.5 \\
\hline \multicolumn{5}{|l|}{ Haplorchis taichui } \\
\hline Chanodichthys erythropterus & 30 & 36.7 & $1-8$ & 3.3 \\
\hline Saurogobio immaculatus & 10 & 70.0 & $1-44$ & 9.4 \\
\hline Garra imbarbatus & 2 & 100 & $16-90$ & 53.0 \\
\hline Subtotal & 42 & 47.6 & $1-90$ & 10.3 \\
\hline \multicolumn{5}{|l|}{ Centrocestus formosanus } \\
\hline Chanodichthys erythropterus & 30 & 100 & $1-4$ & 1.8 \\
\hline Toxabramis houdemeri & 20 & 5.0 & - & 1.0 \\
\hline Saurogobio immaculatus & 10 & 50.0 & $1-9$ & 3.4 \\
\hline Subtotal & 60 & 31.7 & $1-9$ & 2.2 \\
\hline
\end{tabular}

an experimental hamster) were flat, elongate leaf-like, tapering anteriorly and somewhat pointed posteriorly, and 5.75-12.0 (av. 8.98) mm long and 1.55-2.15 (1.84) mm wide. Eggs were small, yellowish, mature, operculate, and 25-28 (26) by 13-14 (13) $\mu \mathrm{m}$ in size.

In the present study, 4 species of zoonotic trematode metacercariae, i.e., C. sinensis, H. pumilio, H. taichui, and C. formosanus, were detected in fish from a local market of Yen Bai city, Yen Bai province, northern Vietnam. Among these, C. sinensis metacercaria (CsMc) was the dominant species with regard to the intensity of infection in fish hosts (81.2 CsMc per fish infected). Chai et al. [8] found 6 species of ZTM, i.e., H. taichui, H. pumilio, C. formosanus, Procerovum varium, Stellantchasmus falcatus, and Heterophyopsis continua, in fish from Hanoi and Nam Dinh province, Vietnam. They were all intestinal flukes belonging to the family Heterophyidae, and $H$. pumilio was the dominant species. Phan et al. [19] also detected 6 species of ZTM, i.e., H. pumilio, H. taichui, H. yokogawai, C. formosanus, P. 
varium, and C. sinensis, in cultured and wild-caught freshwater fish from the Red River delta, in Nam Dinh province. H. pumilio was also the dominant species, and CsMc were found in only 1 out of 1,543 fish examined. Hung et al. [22] also detected 6 species of ZTM, i.e., H. pumilio, H. taichui, H. yokogawai, C. formosanus, P. varium, and C. sinensis, in fish from Ninh Binh province. Among them, Haplorchis spp. metacercariae were dominant, and CsMc were found in only 1 (12.5\%) out of 8 Hemiculter leucisculus examined. In our study, CsMc were highly prevalent in several species of fish from Yen Bai city, Yen Bai province unlike in previous studies performed in adjacent localities of the other northern parts of Vietnam, i.e., Hanoi, Nam Dinh, and Ninh Binh province.

Two species of human-infecting liver flukes, C. sinensis and Opisthorchis viverrini, are known to be distributed in Vietnam. The former is prevalent in northern provinces, whereas the latter is mainly found in central and southern provinces [25]. In previous studies, the metacercariae of liver flukes were very rarely detected in fish from Vietnam. Only 19 O. viverrini metacercariae in total were found in 1.9\% of fish from An Giang province, in the Mekong Delta of Vietnam [12]. In addition, Thien et al. [13] could not find CsMc at all in 13 species of cultured fish from the Mekong Delta area. Also, in Nghe An province, no liver fluke metacercariae were detected among farmed fish [15].

With regard to $C$. sinensis, the metacercariae were found in 1 of 1,185 silver carps, Hypophthalmichthys molitrix, from smallscale farms in northern parts, and in 1 out of 1,543 freshwater fish from Red River delta in Nam Dinh province $[18,19]$. Hung et al. [22] also detected CsMc in 1 (12.5\%) of 8 H. leucisculus examined. In other northern provinces, prevalences of CsMc were very low, $0.1-0.4 \%$ [21]. However, in the present study, we detected a very high intensity of CsMc (81.2 per fish infected) from $69.7 \%$ freshwater fish in 5 species, i.e., C. erythropterus, T. houdemeri, S. immaculatus, O. bidens, and S. atromaculatus. In addition, it has been first confirmed in this study that 2 fish species, C. erythropterus and T. houdemeri, are highly susceptible for CsMc.

Clonorchiasis is known to be endemic among the residents of northern provinces of Vietnam. Especially, this disease was known to be prevalent in Nam Dinh and Ninh Binh provinces [25]. However, since the FIBOZOPA (Fish-Borne Zoonotic Parasite) project (2004-2012), it became known that various species of minute intestinal trematodes, i.e., H. pumilio, $H$. taichui, H. yokogawai, C. formosanus, S. falcatus, and P. varium, co- existed in these areas $[3,8,18,19,21,22]$. Dung et al. [3] reported $64.9 \%$ positive rate of minute trematode eggs from 615 residents of Nam Dinh province, and they recovered 6 species of trematode adults, i.e., C. sinensis, H. pumilio, H. taichui, H. yokogawai, S. falcatus, and Fasciolopsis buski, from 33 residents positive for small trematode eggs after treatment with praziquantel and purging with $\mathrm{MgSO}_{4}$. Adult worms of $C$. sinensis were recovered from 17 (51.5\%) residents, and the intensity of infection was 4 worms in average, whereas adults of $H$. pumilio and H. taichui were recovered from all 33 (100\%) and 23 (69.7\%) residents, with the infection intensities of 416 and 40 in average, respectively. Likewise, in endemic areas of clonorchiasis in northern Vietnam, the coexistence of minute intestinal trematodes has been confirmed by ZTM studies performed in the same survey areas $[8,18,19,21,22]$.

Several working groups reported the morphological characteristics of ZTM with their infection status in fish hosts from the specific regions in Southeast Asian countries [8-11]. Especially in Vietnam, Chai et al. [8] described the morphological characteristics of 6 species of ZTM, i.e., H. taichui, H. pumilio, C. formosanus, P. varium, S. falcatus, and H. continua, from fish in Hanoi city and Nam Dinh province, and they also described the morphologies of adult flukes, i.e., H. taichui, $H$. pumilio, $C$. formosanus, P. varium, and $S$. falcatus, recovered from experimentally infected animals. In our study, C. sinensis metacercariae were nearly the same size $(140-175 \times 120-160 \mu \mathrm{m})$ as those of the Korean-origin $(150-170 \times 130-150 \mu \mathrm{m})$, but they are, more or less, smaller than those of O. viverrini (190-250 × 150$220 \mu \mathrm{m})[5,6,11]$. Because of the general morphology of the metacercariae, including the elliptical shape, nearly same sized 2 suckers, brownish pigment granules in the body, and Oshaped excretory bladder, of 2 species of liver flukes is very similar except for the cyst size, it is difficult to distinguish one from the other if they are mixed-infected. Therefore, when the metacercariae of liver flukes are detected in fish from somewhere of Vietnam, it would be better to infect them to experimental animals to obtain adult flukes for species identification. Adult worms of $C$. sinensis in this study were more slender compared to those of the Korean-origin. The ratio of the body length to body width was higher (4.87-5.01 in this study) than that of the Korean-origin (4.36) (Table 3). Other morphological characters of $C$. sinensis adults were almost the same in both origins. However, the egg size was more or less smaller in this study $(25-28 \times 13-14 \mu \mathrm{m})$ than those of the Korean-origin $(27-33 \times 15-19 \mu \mathrm{m})$. 
Conclusively, it has been confirmed in this study that several species of freshwater fish continue to play the role of the second intermediate host and infection source of zoonotic trematodes, including C. sinensis and 3 species of intestinal flukes in Yen Bai province, Vietnam. In particular, the prevalence and intensity of CsMc were much higher in this study than those of previous studies. To reveal the detailed epidemiological situation of zoonotic trematode infections in Yen Bai province, Vietnam, more profound studies on intermediate (snail and fish) and definitive hosts (humans and reservoir host animals) should be performed in the near future.

\section{ACKNOWLEDGMENTS}

We thank Jung-A Kim and Hee-ju Kim, Department of Parasitology and Tropical Medicine, Gyeongsang National University College of Medicine, Jinju, Korea, for their help in fish examinations.

\section{CONFLICT OF INTEREST}

The authors declare no conflict of interest related to this study.

\section{REFERENCES}

1. WHO. Food-Borne Trematode Infections in Asia. Report Joint WHO/FAO Workshop, Hanoi, Vietnam, 2002.

2. Chai JY, Murrell KD, Lymbery A. Fishborne parasitic zoonoses: status and issues. Int J Parasitol 2005; 35: 1233-1254.

3. Trung Dung D, Van De N, Waikagul J, Dalsgaard A, Chai JY, Sohn WM, Murrell KD. Fishborne intestinal zoonotic trematodiasis, Vietnam. Emerg Infect Dis 2007; 13: 1828-1833.

4. Chai JY. Human Intestinal Flukes. From Discovery to Treatment and Control. GX Dordrecht,the Netherlands. Springer Nature BC. 2019, pp 1-520.

5. Sohn WM. Fish-borne zoonotic trematode metacercariae in the Republic of Korea. Korean J Parasitol 2009; 47(suppl): 1-10.

6. Sohn WM. Trematodes: Platyhelminthes: Trematoda: Strigeidida, Echinostomida, Plagiorchiida, Posithorchiida. Incheon, Korea. The National Institute of Biological Resources. 2013, pp $1-125$.

7. Sohn WM, Eom KS, Min DY, Rim HJ, Hoang EH, Yang Y, Li X. Fishborne trematode metacercariae in freshwater fish from Guangxi Zhuang Autonomous Region, China. Korean J Parasitol 2009; 47: 249-257.

8. Chai JY, De NV, Sohn WM. Foodborne trematode metacercariae in fish from northern Vietnam and their adults recovered from experimental hamsters. Korean J Parasitol 2012; 50: 317-325.

9. Chai JY, Sohn WM, Na BK, Yong TS, Eom KS, Yoon CH, Hoang EH, Jeoung HG, Socheat D. Zoonotic trematode metacercariae in fish from Phnom Penh and Pursat, Cambodia. Korean J Parasitol 2014; 52: 35-40.

10. Chai JY, Sohn WM, Na BK, Park JB, Jeoung HG, Hoang EH, Htoon TT, Tin HH. Zoonotic trematode metacercariae in fish from Yangon, Myanmar and their adults recovered from experimental animals. Korean J Parasitol 2017; 55: 631-641.

11. Chai JY, Lee SH, Rim HJ, Sohn WM, Phommasack B. Infection status with zoonotic trematode metacercariae in fish from Lao PDR. Acta Trop 2019; 199: 105-100.

12. Thu ND, Loan LTT, Dalsgaard A, Murrell KD. Survey for zoonotic liver and intestinal trematode metacercariae in cultured and wild fish in An Giang Province, Vietnam. Korean J Parasitol 2007; 45: 45-54.

13. Thien PC, Dalsgaard A, Bui NT, Olsen A, Murrell KD. Prevalence of fishborne zoonotic parasites in important cultured fish species in the Mekong Delta, Vietnam. Parasitol Res 2007; 101: $1277-1284$.

14. Hop NT, De NV, Murrell KD, Dalsgaard A. Occurrence and species distribution of fishborne zoonotic trematodes in wastewater-fed aquaculture in northern Vietnam. Trop Med Int Health 2007; 12: 66-72.

15. Chi TT, Dalsgaard A, Turnbull JF, Tuan PA, Murrell KD. Prevalence of zoonotic trematodes in fish from a Vietnamese fish farming community. J Parasitol 2008; 94: 423-428.

16. Vo DT, Murrell D, Dalsgaard A, Bristow G, Nguyen DH, Bui TN, Vo DT. Prevalence of zoonotic metacercariae in two species of grouper, Epinephelus coioides and Epinephelus bleekeri, and flathead mullet, Mugil cephalus, in Vietnam. Korean J Parasitol 2008; 46: 77-82.

17. Tran TKC, Dalsgaard A, Turnbull JF, Tuan PA, Murrell KD. Prevalence of zoonotic trematodes in fish from a Vietnamese fishfarming community. J Parasitol 2008; 94: 423-428.

18. Phan VT, Ersbøll1 AK, Nguyen KV, Madsen H, Dalsgaard A. Farm-level risk factors for fishborne zoonotic trematode infection in integrated small-scale fish farms in northern Vietnam. PLoS Negl Trop Dis 2010; 4: 742-750.

19. Phan TV, Ersbøll AK, Bui TQ, Nguyen HT, Murrell D, Dalsgaard A. Fishborne zoonotic trematodes in cultured and wild-caught freshwater fish from Red River delta, Vietnam. Vector Borne Zoonotic Dis 2010; 10: 861-866.

20. Bui TD, Madsen H, Dang TT. Distribution of freshwater snails in family-based VAC ponds and associated water bodies with special reference to intermediate hosts of fishborne zoonotic trematodes in Nam Dinh province, Vietnam. Acta Trop 2010; 116: 1523.

21. De NV, Le TH, Murrell KD. Prevalence and intensity of fishborne zoonotic trematodes in cultured freshwater fish from rural and urban areas of northern Vietnam. J Parasitol 2012; 98: 1023-1025.

22. Hung NM, Dung DT, Anh NTL, Van PT, Thanh BN, Ha NV, Hien 
HV, Canh LX. Current status of fishborne zoonotic trematode infections in Gia Vien district, Ninh Binh province, Vietnam. Parasit Vectors 2015; 8: 21-30.

23. Information on Yen Bai province, Vietnam [Internet]; Available from: http://en.wikipedia.org.
24. Identification of fish species (Search fishbase) [Internet]; Available from: https://www.fishbase.se/search.php

25. Doanh PN, Nawa Y. Clonorchis sinensis and Opisthorchis spp. in Vietnam: current status and prospects. Trans R Soc Trop Med Hyg 2016; 110: 13-20. 